\title{
Can Exergames Use As an Educational Tool in Physical Education for Cognitive, Social, and Affective Domains?
}

\author{
Yakup Zuhtu Birinci (Corresponding author) \\ Bursa Uludag University, Faculty of Sport Sciences, Bursa, Turkey \\ E-mail: ykpbirinci@gmail.com \\ Nimet Hasil Korkmaz \\ Bursa Uludag University, Faculty of Sport Sciences, Bursa, Turkey \\ E-mail: nhasil@uludag.edu.tr \\ Inci Ece Ozturk \\ Bursa Uludag University, Faculty of Sport Sciences, Bursa, Turkey \\ E-mail: incieceozturk@gmail.com
}

\begin{abstract}
The rapid growth of children's interest in the digital world leads educators to use this interest to meet learning outcomes. In this respect, the use of computer-based simulations and video games as educational tools is a necessity rather than an innovative method for educators. In recent years, school-based physical activity (PA) programs based on active video games/exergames (EG) have begun to be implemented. The aim of this review was to investigate the effects of EG as an educational tool in physical education (PE) lessons in terms of children's social, affective, and cognitive domains. The literature obtained by researching in Pubmed, Uludağ E-Library and Google Academic databases without date limitation was examined with systematic review methodology. In conclusion, EG creates the potential to have a positive impact on social, cognitive and affective domain skills such as PA perception, collaboration, leadership, self-management, motor learning, memory, awareness and peer learning. Even if EG alone does not replace a teacher or a lesson, it can enrich the learning environment in PE. EG can be not only an important source of motivation for active participation in PE lessons for children but also an effective educational tool for the teacher.
\end{abstract}

Keywords: Active Video Games, Exergames, Physical Education

\section{Special Issue of Educational Sciences}

DOI: $10.7176 / J S T R / 6-06-11$

\section{Introduction}

According to the World Health Organization (WHO), health is defined as: " Health is a state of complete physical, mental and social well-being and not merely the absence of disease or infirmity". When considered in this respect, PE is an important health related area. Because it is an educational process that aims to improve the social, affective and cognitive fields of the person as well as physical development through body movements. PE creates an enriching learning environment. This learning environment includes taking different roles, recognizing strengths and weaknesses, feeling of justice, competition, leadership and respect, developing strategy and tactics, following rules and guidelines, memory, motivation, attention, analytical thinking and motor learning (Bailey et al., 2009). Thus, the educational environment of PE makes a very important contribution to the preparation process of children for life (Bailey et al., 2005; Lu \& Buchanan, 2014).

The PE teacher does not just want the children to follow the instructions physically. At the same time, teachers should create different environments to activate cognitive domain. In order to influence the cognitive domain, the teacher should engage in a wide variety of activities that develop problem solving, strategy and creativity mechanisms. For social purposes, students can improve themselves in many fields such as cooperation, responsibility, leadership, peer communication. PE activities also contribute to the

$\mathbf{1 5 1} \mid \mathrm{P}$ a g e

www.iiste.org 
affective field by enabling the person to experience processes such as self-control, self-discovery, entertainment and motivation (Dyson \& Grineski, 2001; Tunçel, 2006). In this context, games play a very important role in supporting children's developmental areas. But the sedentary behavior has increased as traditional games and street games are not as popular among children as before (Tuğrul, et al., 2014). At the same time, the fatiguing and boring perception of the PA and the dramatic increase in screen addiction are gradually reducing children's interest in PE (Knowles et al., 2011; Whitehead and Biddle, 2008; Slater and Tiggemann, 2010). This situation also makes difficult for PE teachers to encourage their students to move. Some studies reveal that sedentary life not only leads to an increased risk of developing cardiovascular and metabolic diseases, but may also be associated with conditions such as depression, suicidal ideation, low self-esteem, bullying, anxiety, and low self-perception (Carpenter, 2000; Reulbach, 2013; Selewski et al., 2013; Vuuren et al., 2019). For this reason, the goal of making students acquire regular PA habits in PE at children and adolescents has gained great meaning today as a preventive health intervention. To overcome these challenges, teachers need to develop teaching methods using student-centered, interesting and fun teaching materials. While PE teachers encourage students to be an active, they have started to include technological devices that attract intense attention of students in their lessons.

One of these electronic devices, Exergames, are systems in which players perform various body movements in accordance with the instructions on the screen and that these movements are perceived by the device to control the game. EG are video games that contain physical exercise (Staiano \& Calvert, 2011) and are very popular among children (O'Loughlin et al., 2012), including children who are overweight or who report being excluded from competitive team sports (Biddiss \& Irwin, 2010; Staiano et al., 2019). During EG, children can consume a significant amount of energy by having PA while having fun (Lamboglia et al., 2013). Thus, children's PA levels may increase. Many studies demonstrate that EG have the potential to spend energy equal to children with moderate to high intensity PA (Gao \& Chen, 2014; Gao et al., 2015). In addition, it is thought that the use of EG may be beneficial for the students who are reluctant to participate in the PA and have lower skill level to be included in the PE processes (Ennis, 2013; Çoknaz et al., 2019; Staiano et al., 2013).

Besides physical benefits, EG has options that allow socialization, increase motivation, provide feedback, active learning, transfer knowledge and skills. Having various difficulty levels suitable for everyone has made it technological equipment compatible with the educational process (Oblinger, 2004). According to Winn (2002), considering today's digital world, the use of such games in education is not only an alternative for educators, but also a requirement for ensuring student motivation. Indeed, considering the new generations born in a technological world, the teachers' inadequacy in technology and being unable to adapt these contents to their own area may result in the problem of not meeting student needs. Since positive emotions and feelings have an impact on learning, the teacher needs to increase student motivation by turning interest in technology into an advantage. Self-efficacy perception and entertainment are also important sources of motivation for participation in PA (McNeille, 2019). PE efficiency will increase when the teacher avoids repetitive activities and creates activities where children can experience the feeling of success and fun. When considered from this point of view, it is thought that it may be important to use EG as a teaching material for PE teachers.

Although technologies such as EG are loved by the students, it is thought that they cannot replace the whole PE (Sheehan \& Katz, 2010; Sun, 2012) and student interest can be lost by repeating it too much (Sun, 2013). PE teachers should pay attention to the types of games, the playing time per student, the electronic infrastructure of the school and environmental safety while using EG.

The aim of this review was to investigate the effects of EG as an educational tool in physical education lessons in terms of children's social, affective, and cognitive domains.

\section{Method}

This systematic review, which was made especially to determine the effectiveness of EG used during PE, consists of two separate sections. In this systematic review, "What are the effects of EG included in PE in terms of social, cognitive and affective domains on children?" started with the question. Systematic review method was used in the present study. This method is frequently used in terms of revealing important relationships in the literature, offering recommendations for further studies and being a resource (Nacakc1 et al., 2017). Review was prepared under the guidance of Center for Reviews and Dissemination (CRD) 2009, developed by the University of York National Institute for Health Research. Preferred Reporting Items for Systematic Reviews and Meta-Analyzes (PRISMA) was used as a methodology in electronic database research (Moher et al., 2009).

$\mathbf{1 5 2} \mid \mathrm{P}$ a g e

www.iiste.org 
A literature review was conducted between February and March 2020 in the Pubmed, Uludağ University Elibrary, Google Scholar databases without any restrictions in terms of years. During the search, 5 keywords were used in 3 English and 2 Turkish. "aktif video oyunları", "aktif video oyunları ve beden eğitimi", "active video games", "exergames", "exergames and physical education" are the keywords used in the screening. The number of articles accessed from all databases within the scope of scanning is 3556. Apart from electronic scanning, articles obtained from the sources of related articles were also investigated. 135 studies were reached when repeated, written in other languages, reviews, irrelevant and non-full text were excluded. As a result of the articles evaluated for suitability, the number of articles examined within the scope of the study was 29 (Figure 1).

\section{Inclusion criteria}

i. focus on educational outcomes of exergames,

ii. usage of commercially home-based video games consoles, iii. publications limited in English and Turkish language,

iv. the experimental intervention group is school-age children,

v. the type of game suitable for school use.

\section{Exclusion criteria}

i. studies on technological aspect of the video game such as software development and hardware specifications,

ii. physiological, sensorimotor functioning and skill training outcomes,

iii. reviews.

The methodological approaches and sample size in the studies were not considered.
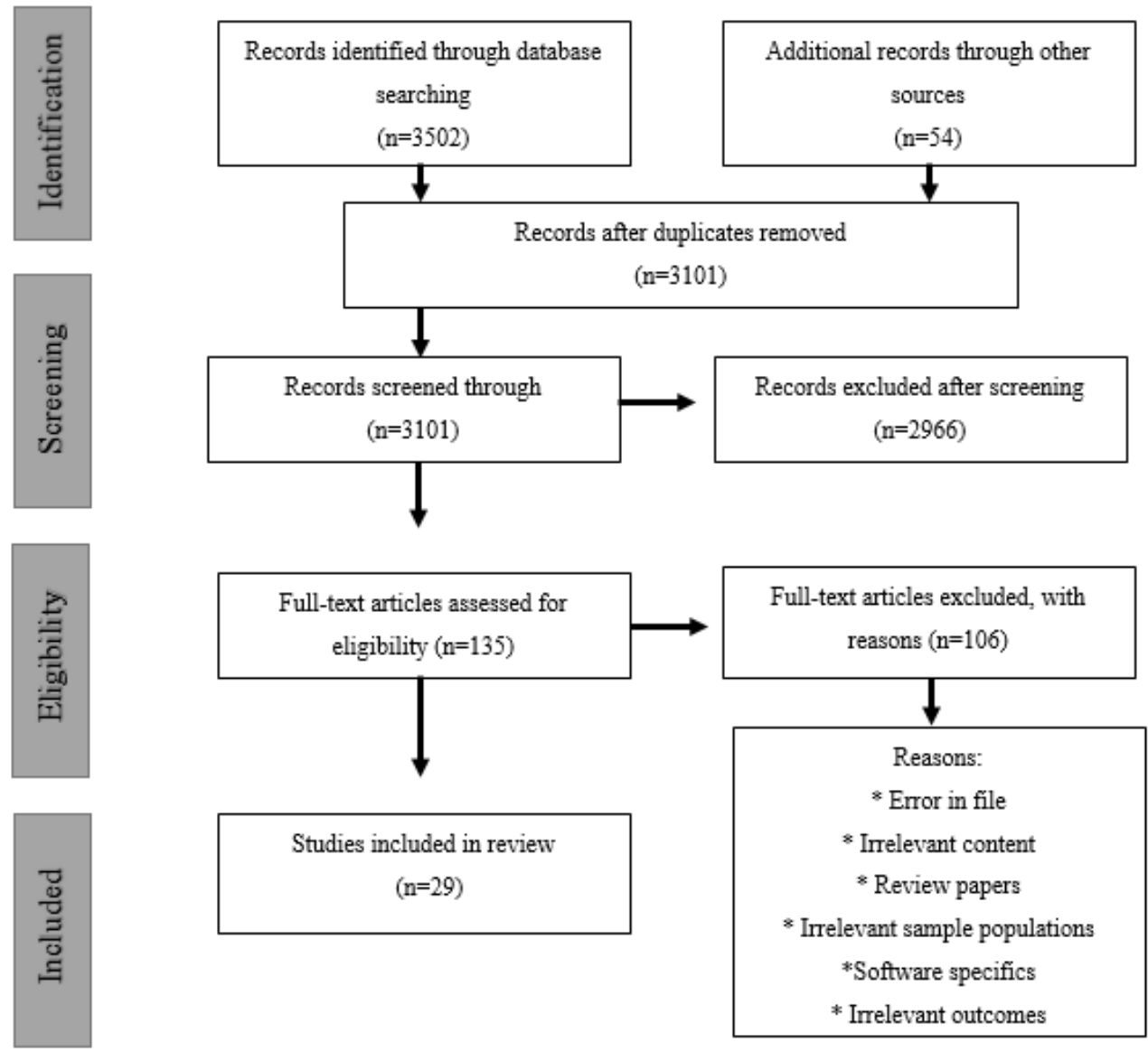

Figure 1. PRISMA flow chart 
Table 1. Exergames studies

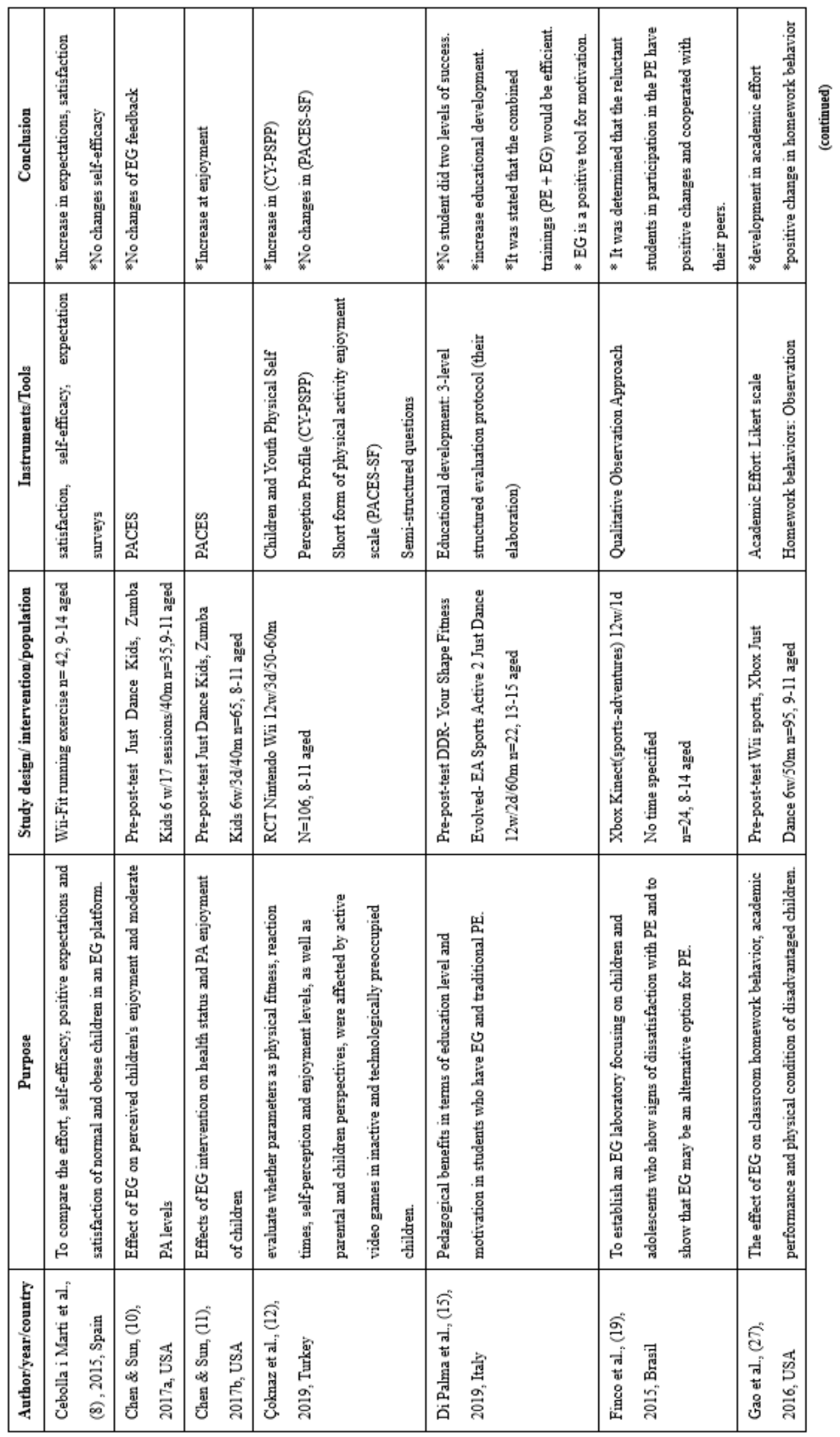


Table 1. Continued

\begin{tabular}{|c|c|c|c|c|c|c|c|}
\hline 8 & 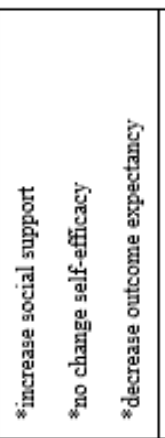 & 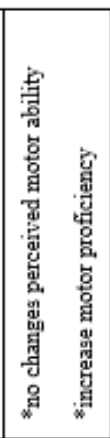 & 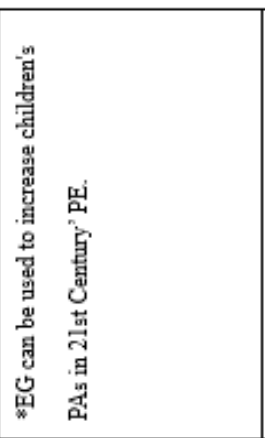 & 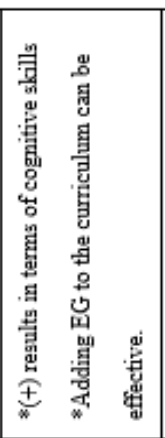 & 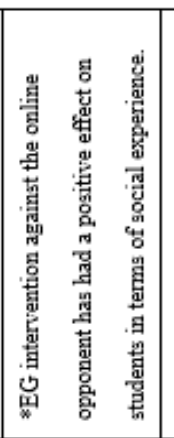 & 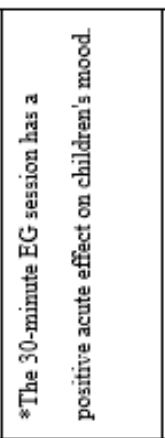 & 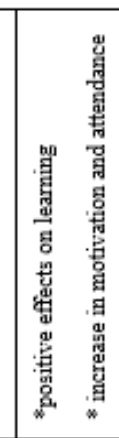 \\
\hline 递 & 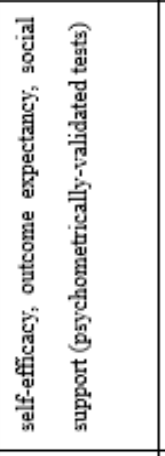 & 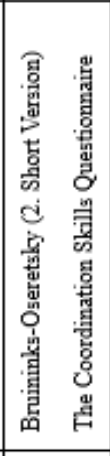 & 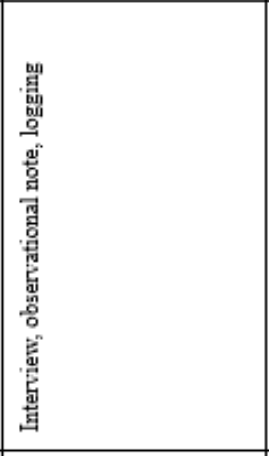 & 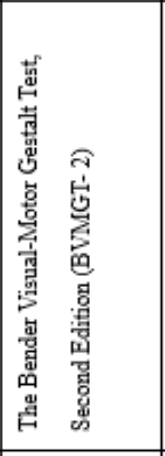 & 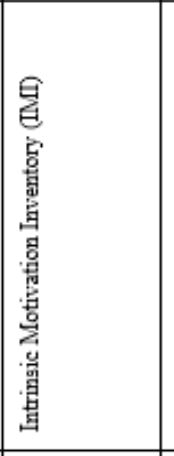 & 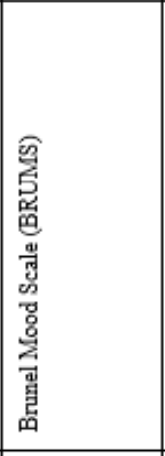 & 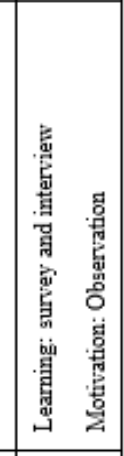 \\
\hline 直 & 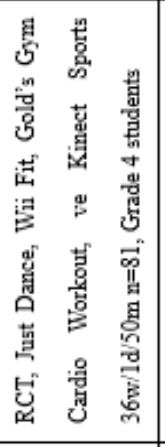 & 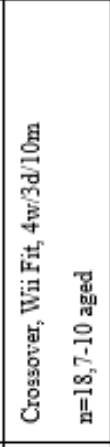 & 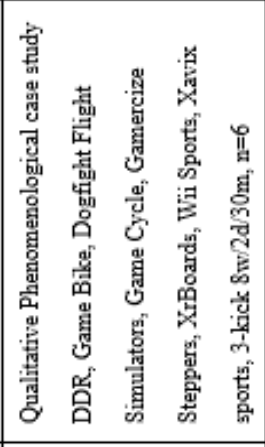 & 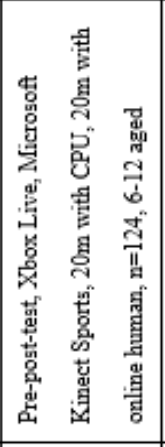 & 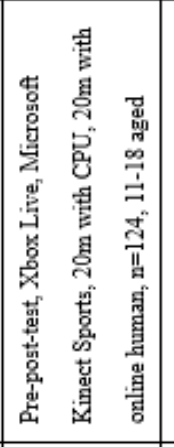 & 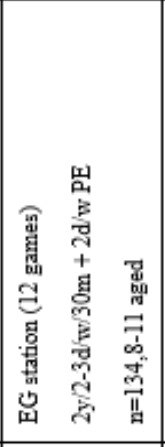 & 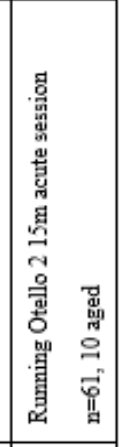 \\
\hline & 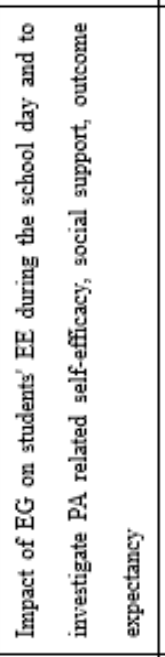 & 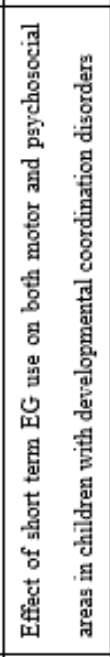 & 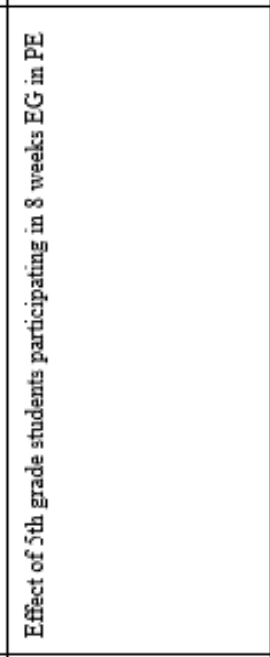 & 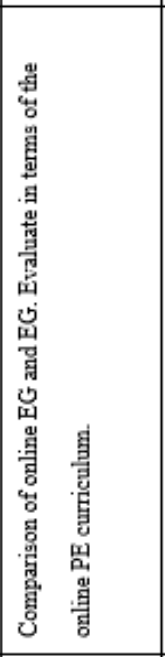 & 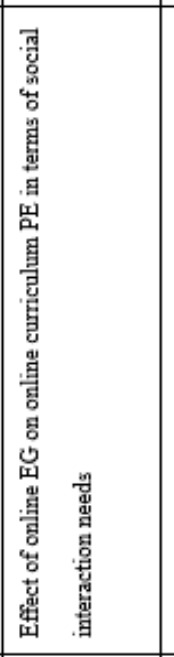 & 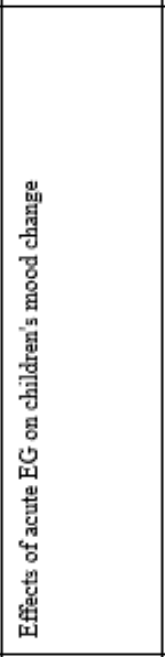 & 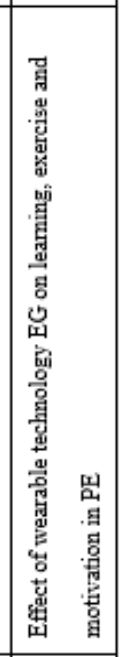 \\
\hline & 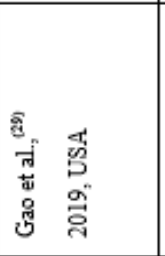 & 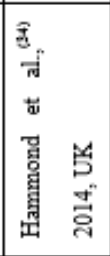 & 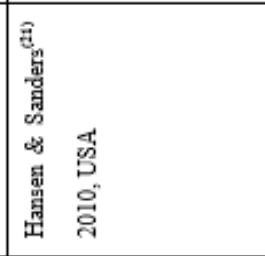 & 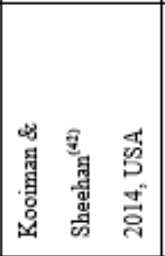 & 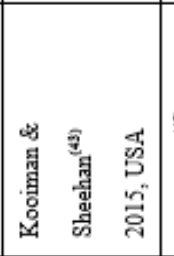 & 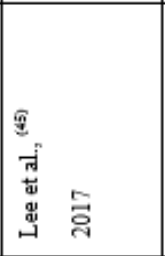 & 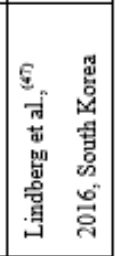 \\
\hline
\end{tabular}


Table 1. Continued

\begin{tabular}{|c|c|c|c|c|c|c|c|c|c|c|c|}
\hline & 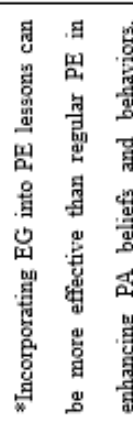 & 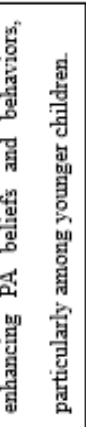 & 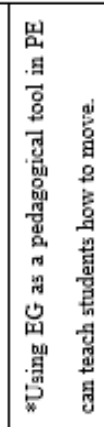 & 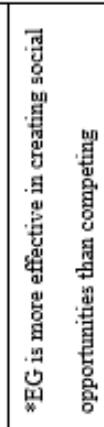 & 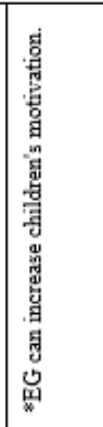 & 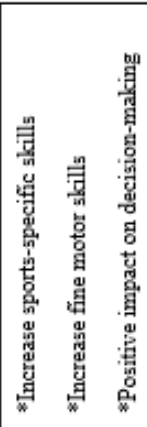 & 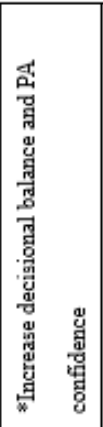 & 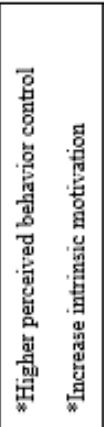 & 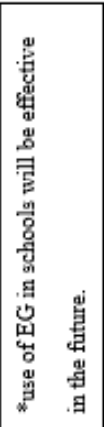 & 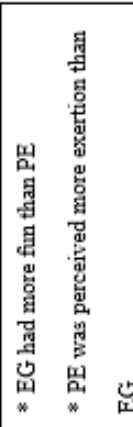 & \\
\hline & 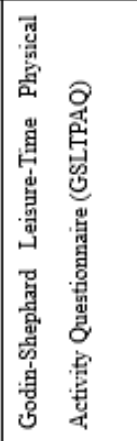 & & 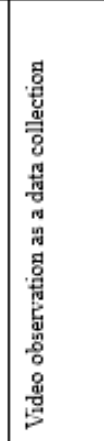 & 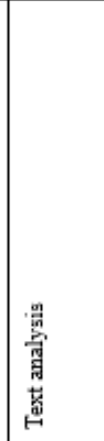 & 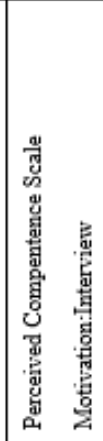 & 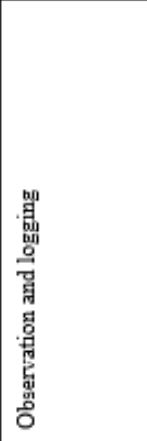 & 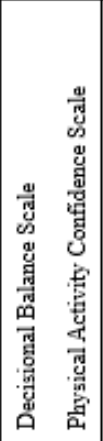 & 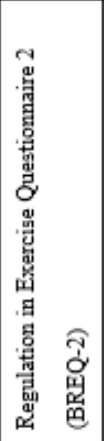 & 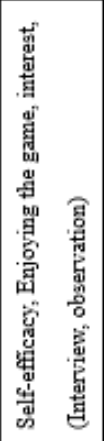 & 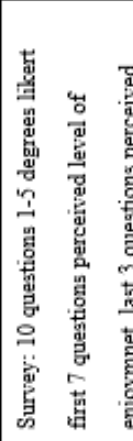 & 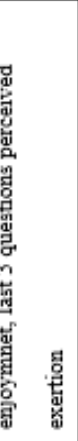 \\
\hline & 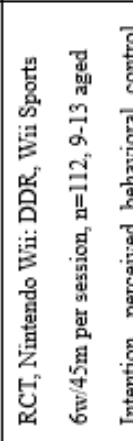 & 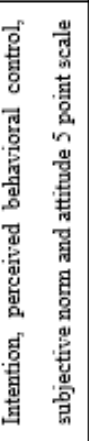 & 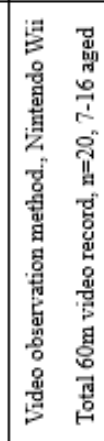 & 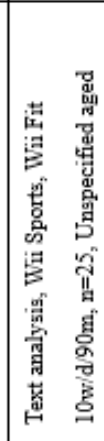 & 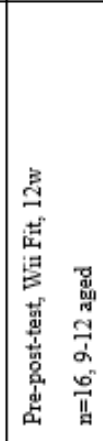 & 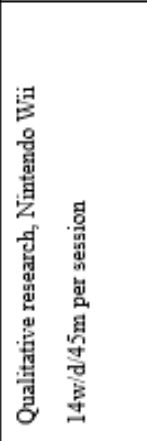 & 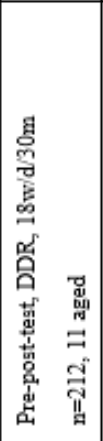 & 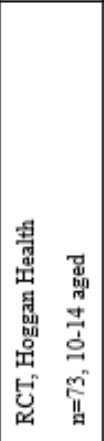 & 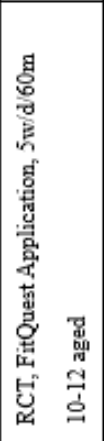 & 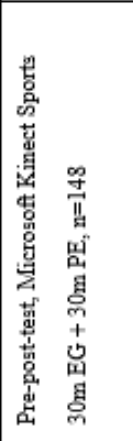 & \\
\hline & 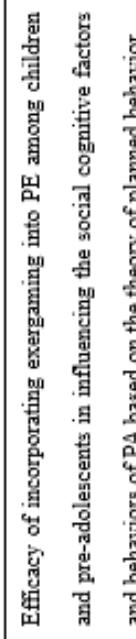 & 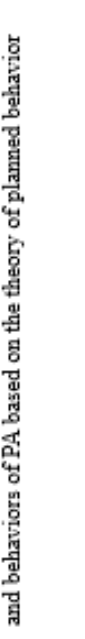 & 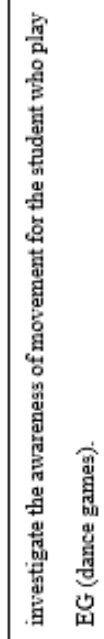 & 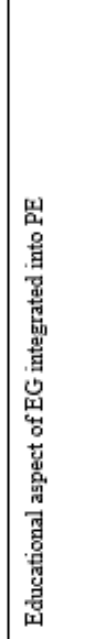 & 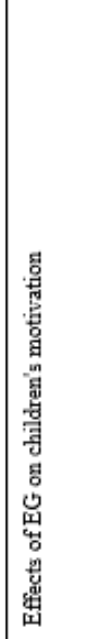 & 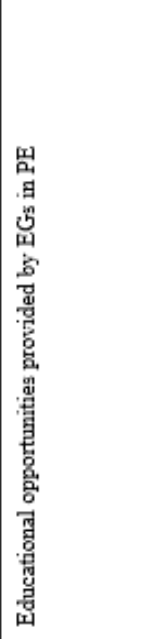 & 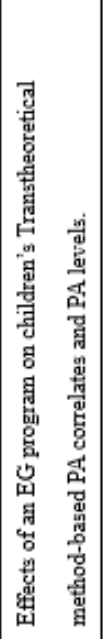 & 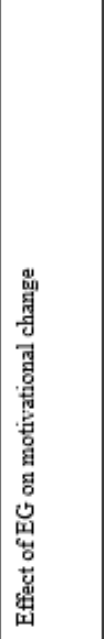 & 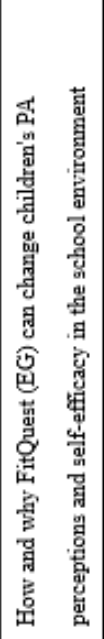 & 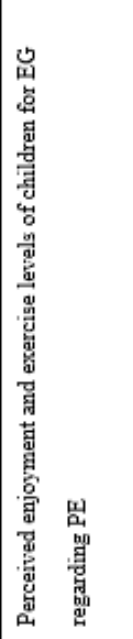 & \\
\hline & 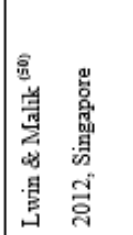 & & 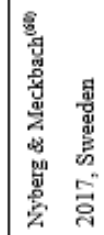 & 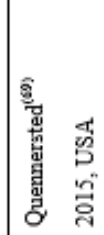 & 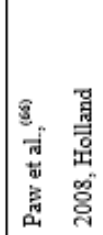 & 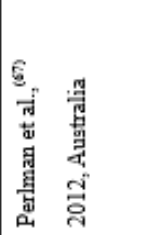 & 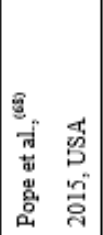 & 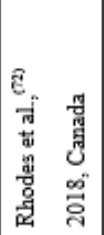 & 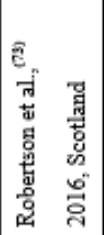 & 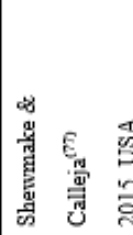 & \\
\hline
\end{tabular}


Table 1. Continued

\begin{tabular}{|c|c|c|c|c|c|c|}
\hline ठ8 & 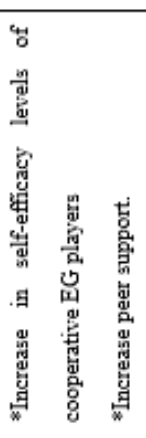 & 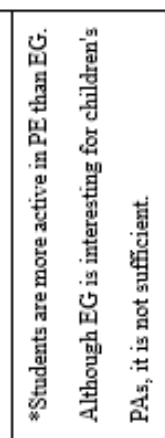 & 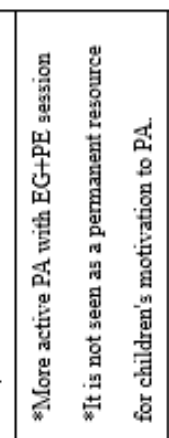 & 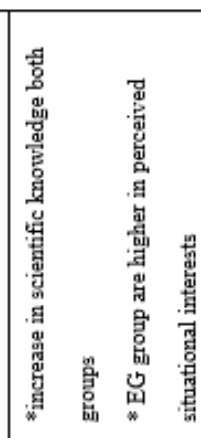 & 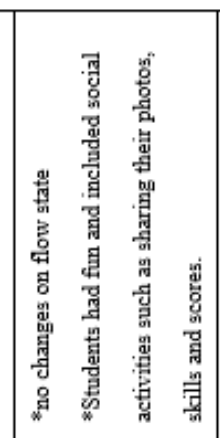 & 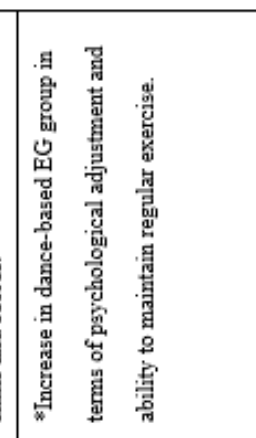 \\
\hline 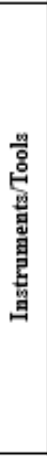 & 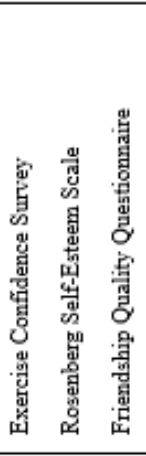 & 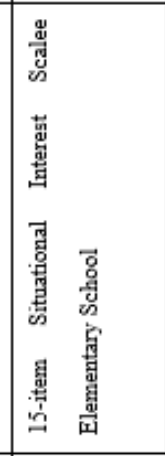 & 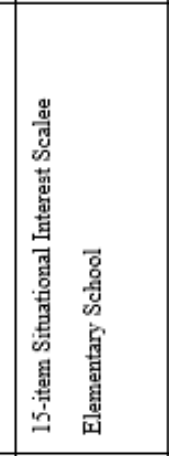 & 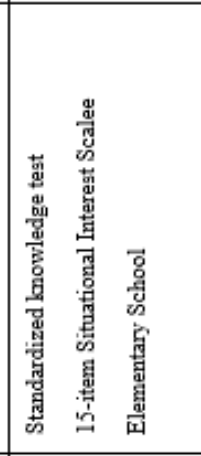 & 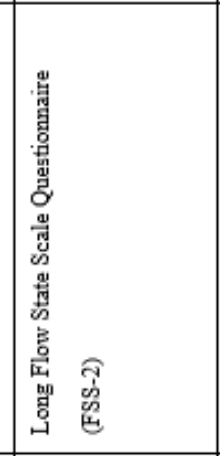 & 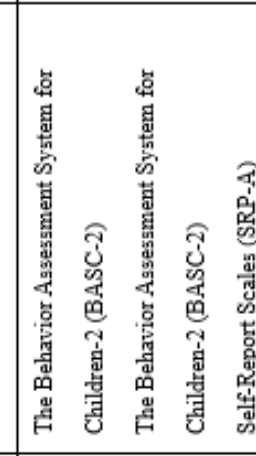 \\
\hline 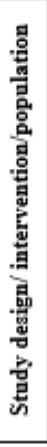 & 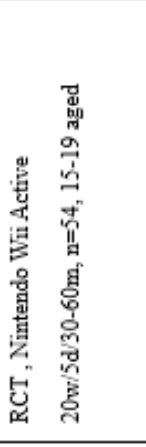 & 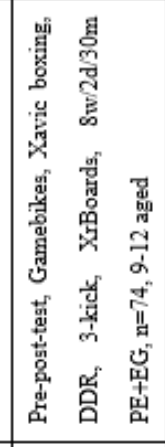 & 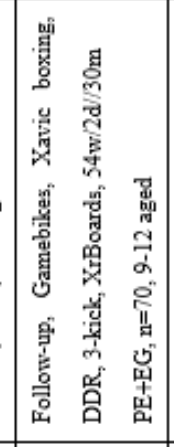 & 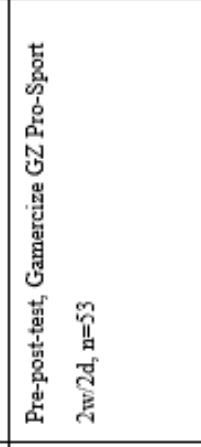 & 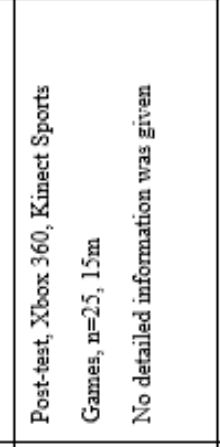 & 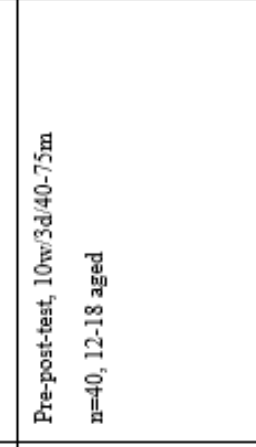 \\
\hline & 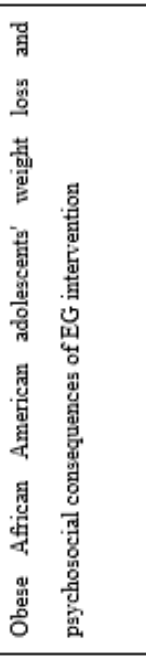 & 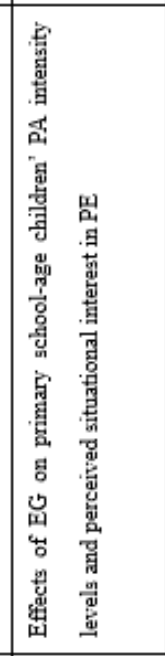 & 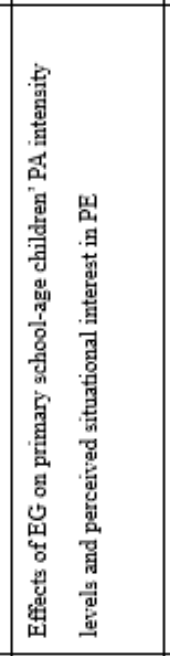 & 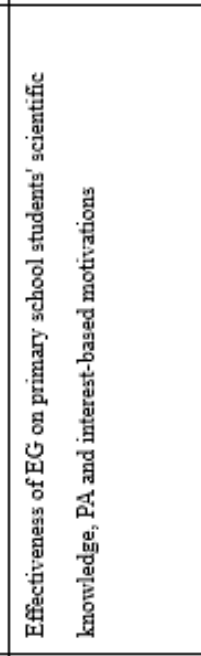 & 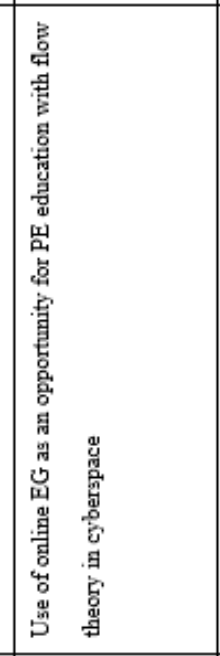 & 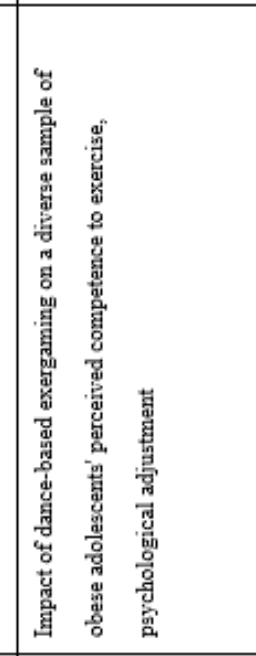 \\
\hline & 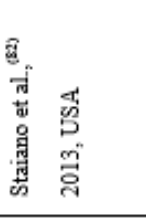 & 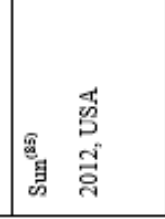 & 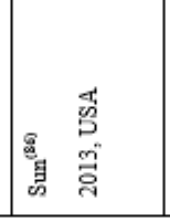 & 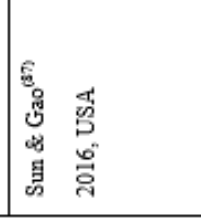 & 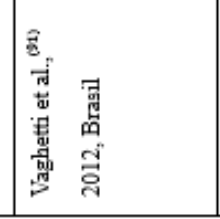 & 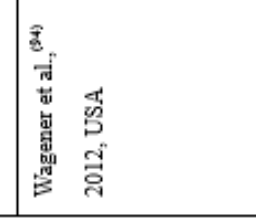 \\
\hline
\end{tabular}


In this section, the effect of EG on the social, cognitive and affective domains of children will be examined with the studies in the literature. Because learning domains are interrelated and can be included in PE learning objectives (Figure 2).

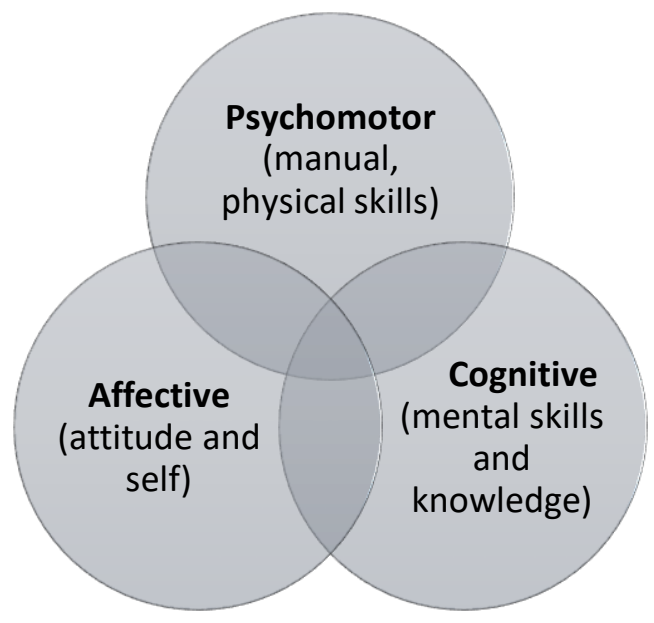

Figure 2. Learning Domains (McKenzie et al., 2017)

3.1. The effects of exergames on social domain. EG and other video games are often played with peers, due to this they can provide opportunities for social interaction. EG interaction can have a positive effect on friend choice, friendship, self-esteem, mood and motivation. Thus, it can reduce the risk of social isolation and loneliness (Coknaz et al., 2019; Di Palma et al., 2019; Mueller et al., 2003; Staiano \& Calvert, 2011). According to the study of Lieberman (2006), children stated that fun is the main reason for playing dancebased EG. In addition, social interaction, dancing, enjoying the difficulties of the game and admiring their own skills are other reasons for preference. In particular, with an interactive multimedia curriculum; positive development can be observed in psychosocial outcomes such as self-efficacy, social support and the PA attitude. Therefore, children are more likely to increase their PA levels in the future (Gao \& Chen, 2014; Goran \& Reynolds, 2005). Today, children are reluctant to games which adults are authoritarian and can rule. On the contrary, they prefer collaborative games with the rule-setter themselves or their peers. Considering this point of view, EG is an important assistant in terms of peer counseling (Kooiman \& Sheehan, 2015).

According to Lee et al. (2017), the multi-mode feature of EG can enable players to enjoy competition and cooperation. Finco et al. (2015) observed that students who are not motivated to participate in PE have changed their attitudes after the EG added to the lessons. It is stated that they show this motivation of participation in cooperation with their peers. Similarly, Paw et al. (2008) demonstrated that the cooperative multiplayer mode EG has the potential to increases the time spent with PA. Staiano et al. (2011) and Epstein et al. (2007) showed that self-confidence and willingness to participate in PA have increased due to the social interaction provided by EG in obese children. Vaghetti et al. (2012) revealed that children playing EG in online classes can share photos, icons, files, motion experiences and abilities with other players on the network. They thought that interactions with EG from many different cultures and geographies can enrich the learning environment. According to Hansen and Sanders (2010), students can socialize positively during EG by staying in constant peer relationships. They also observed that the students discussed the strategies and instructions about the game, made competitive speeches, participated in the group or included their peers.

3.2. The effects of exergames on cognitive domains. Cognition defines inner mental process activities such as remembering, understanding, applying, analyzing, evaluating and creating (Figure 3). Cognitive development refers to the child's thinking about the objects they see, hear, touch and taste. That is why it is very important for children to obtain, store, interpret, evaluate and transform their own knowledge. PE provides children with a chance to experience their knowledge through physical exercises. It is important that the physical exercises in the lesson are rich in cognitive stimuli. Physical exercise, which creates a cognitively rich environment, is more beneficial in terms of cognitive development than simple physical exercise (Best, 2010). From this point of view, EG develops spatial orientation, attention, memory, and executive function skills by providing aerobic activity. EG can also improve children's ability to respond to

$\mathbf{1 5 8}$ | P a g e

www.iiste.org 
visual stimulus, decision-making, understand spatial constraints, create a cognitive map of body movements and problem-solving (De Lisi \& Wolford, 2002; Höysniemi, 2006; Ko, 2002; Staiano et al., 2012). It is seen that using EG-style games in disciplines such as mathematics, science, language and computer science shows positive outputs in relation to curriculum activities in terms of student motivation and learning effectiveness (Hwang et al., 2013; Papastergiou, 2009; Rosas et al., 2003).

A limited number of studies show that EG can improve academic performance and skills in the game can be transferred to other cognitive activities. For example, Weir (2008) showed that math teacher helps children learn to count by wii bowling game. Similarly, Kooiman and Sheehan (2014) revealed that the use of EG may have a positive effect on cognitive functions.

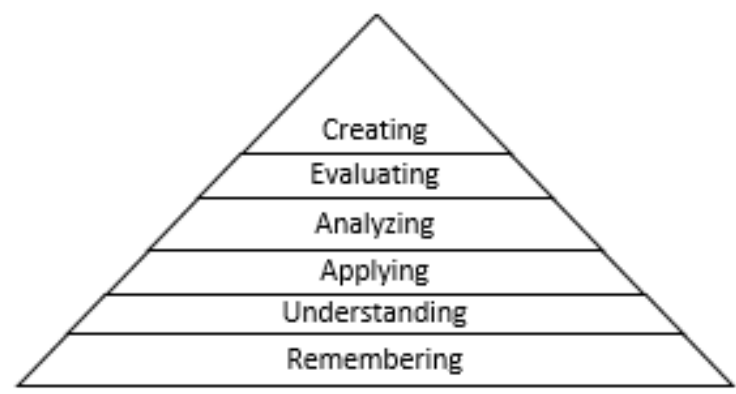

Figure 3. Cognitive domain chart, Revised Taxonomy (Hoque, 2016)

3.3. The effects of exergames on affective domains. Most people think of learning as an intellectual or cognitive functions. However, learning is not a just a mental function. You can also learn attitudes, behaviors, and physical skills. The affective domain involves our feelings, emotions and attitudes (Casey \& FernandezRio, 2019; Hoque, 2016). Frequently more difficult is the development and assessment of affective-domain objectives (Figure 4). It is known that factors such as the diversity of the curriculum they are exposed to, the gender, past PA experiences and general motor ability are affected by children's views on PE (Finn \& McInnis, 2014). At the same time, it is seen that the ridicule and criticism made by their peers and teachers are important obstacles to the positive PA perceptions of children (O'Dea, 2003). So educators may rely on peer-mediated and sportsmanship-related objectives in this area. Affective learning domain also may be easily targeted through non-traditional activities, specifically through the use of challenge course-like innovative activities in the PE (McKenzie et al., 2017). So, can EG provide this innovative situation?

In most studies, it was revealed that PE, in which EG were added, was perceived as more fun and exciting for students (Finco et al., 2015; Graves et al., 2010; Robertson et al., 2016; Shewmake et al., 2015; Thembelihle, 2017). Coknaz et al. (2019) reported that inactive and tech-savvy children had positive emotions such as fun, happiness, excitement, energetics and being active after 12 weeks of EG intervention. EG can improve psychological well-being, including exercise self-efficacy, motivation, enjoyment, and mood in overweight children (Baranowski et al., 2008; Gao et al., 2013; Staiano \& Calvert, 2011). EG can contribute to self-confidence during PA by enabling students to take their eyes from their peers and direct their attention to the screen during the movement (O'Dea, 2003). According to Sun \& Gao (2016) and Watson et al., 2013; EG can be used as an educational tool that makes the curriculum interesting, creating a fun learning environment and attracting student motivation to physical activities. Lee et al. (2017) found a decrease in anger and depression levels in children after 18 weeks of EG intervention in PE. According to Hayes and Silberman (2007), the fact that the games provide unlimited repetition causes them to exhibit less anxiety. In addition, traditional sports have restrictions such as gender differences, different skill levels and safety issues. But with EG, games can be chosen that best meet the talents and fun of children. This can increase children's sport knowledge, perceived abilities, motivation and enjoyment (Wagener et al., 2012). The studies of Danielle et al., (2014) and Sun (2012), reported that approximately 80-90\% of children between the ages of 7-11 prefer PE which integrated EG. While the students who play the game for the first time are more willing to play, but if the game variety is not provided in the future, a decrease in active participation may occur in the PE (Sun, 2013; Gao, 2013; Rhodes et al., 2018).

Unlike these, Vallabhajosula et al. (2016) reported that EG added to PE does not change the perceived fatigue and enjoyment level of students. Coknaz et al. (2019) reported that during EG, few children had negative emotions because of finding the games boring and difficult. And also some children felt depressed and jealous when they lost the game.

$\mathbf{1 5 9} \mid \mathrm{P}$ a g e

WWW.iiste.org 


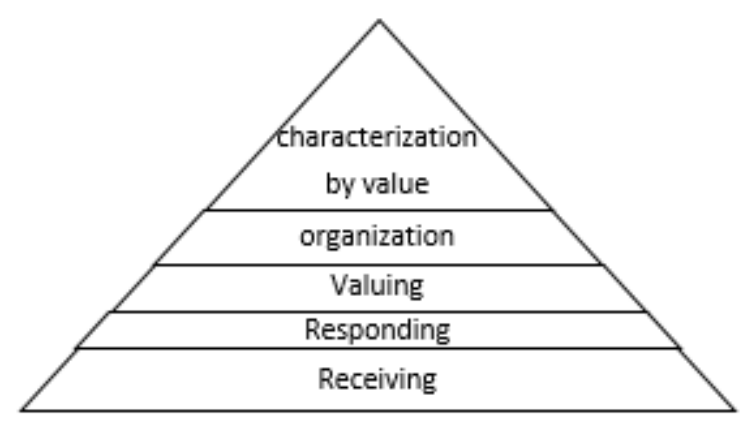

Figure 4. Affective domain chart (Hoque, 2016)

\section{Discussion}

The aim of this review was to investigate the effects of EG as an educational tool in physical education (PE) lessons in terms of children's social, affective, and cognitive domains. In this section, the Republic of Turkey Ministry of National Education's (MNE) educational purposes determined by the scope of PE will be examined. Afterwards, the potential of EG in meeting these objectives will be evaluated. Because in order to use EG as an educational tool, we think that EG should meet the expectations of the country's PE lesson. It is considered that EG can be useful in achieving the general objectives of the Ministry of National Education. Below, it is seen that the objectives planned to be gained in PE lessons match the EG study results in the literature;

* to participate in physical activities and sports regularly to improve health (Gao \& Chen, 2014; Gao et al., 2015; Goran \& Reynolds, 2005; Staiano \& Calvert, 2011),

* acknowledging the existence of others and always behaving honestly and respectfully in their "fair play" behavior and making it a habit (Quennerstedt et al., 2016),

* improving communication skills, collaboration, fair play, social responsibility, leadership, nature awareness and respect for differences (Finco et al., 2015; Lee et al., 2017; Mueller et al., 2003; Staiano \& Calvert, 2011; Paw et al., 2008),

* developing self-management skills (Baranowski et al., 2008; Watson et al., 2013),

* developing movement knowledge and skills by participating in physical activities and making these skills a habit (Robertson et al., 2016; Rudella \& Butz, 2015; Shewmake et al., 2015; Thembelihle, 2017).

In conclusion; EG, has positive effects on social, cognitive and affective domains such as friendship, cooperation, peer support, self-esteem, leadership, loneliness, depression, anger, motivation, creating, problem-solving, memory, sports knowledge, physical exercise perception and motor learning. The use of EG can create motivation to participate in exercise, especially in overweight, obese and unwilling children to participate in PE. It has been observed that children perceive EG as fun and exciting. EG can be an important educational technology support for PE. Even if EG alone does not replace a teacher or a lesson, it can enrich the learning environment in PE. EG can be not only an important source of motivation for active participation in PE lessons for children, but also an effective educational tool for the teacher.

The use of EG can provide effective results in PE, especially in cold weather and adverse environmental conditions, in the design of interdisciplinary lessons, in encouraging individuals to participate in PA, in courses where collaborative learning and self-evaluation are central. Despite all these potential benefits, the increase in randomized controlled experimental studies designed with long-term interventions with large sample groups may provide detailed information about the educational effectiveness of EG. At the same time, studies evaluating the relationship between game types and learning outcomes can be important for the future of the literature.

\section{References}

1. Bailey R. (2005). Evaluating the relationship between physical education, sport and social inclusion. Education Review 57, no. 1: 71-90. 
2. Bailey R. et al. (2009). The educational benefits claimed for physical education and school sport: an academic review, Research Papers in Education, 24:1, 1-27, Doi:10.1080/02671520701809817

3. Baranowski, T. et al. (2008). Playing for real: Video games and stories for health-related behavior change. American Journal of Preventive Medicine, 34, 74-82.

4. Barnes, K. C. (2002). A model health-related elementary physical education program for Saipan: Teachers' knowledge, attitudes, and practices (Unpublished doctoral dissertation). University of San Diego. USA.

5. Best, J. R. (2010). Effects of physical activity on children's executive function: Contributions of experimental research on aerobic exercise. Developmental Review, 30(4), 331-351.

6. Carpenter K.M. et al. (2000). Relationships between obesity and DSM-IV major depressive disorder, suicide ideation, and suicide attempts: results from a general population study. Am J Public Health. 2000; 90(2):251-7

7. Casey, A., \& Fernandez-Rio, J. (2019). Cooperative learning and the affective domain. Journal of Physical Education, Recreation \& Dance, 90(3), 12-17.

8. Cebolla i Martí, A. et al. (2015). Alternative options for prescribing physical activity among obese children and adolescents: brisk walking supported by an exergaming platform. Nutricion hospitalaria, $31(2)$.

9. Centre for Reviews and Dissemination. (2008). Systematic reviews: CRD's guidance for undertaking reviews in health care. University of York, 2008 Published by CRD, University of York: York Publishing Services Ltd, ISBN 978-1-900640-47-3

10. Chen, H., \& Sun, H. (2017a). The Effects of Active Videogame Feedback and Practicing Experience on Children's Physical Activity Intensity and Enjoyment. Games for health journal, 6(4), 200-204.

11. Chen, H., \& Sun, H. (2017b). Effects of Active Videogame and Sports, Play, and Active Recreation for Kids Physical Education on Children's Health-Related Fitness and Enjoyment. Games for Health Journal, 2017 6:5, 312-318.

12. Coknaz, D. et al. (2019). Digital movement in the world of inactive children: favourable outcomes of playing active video games in a pilot randomized trial. Eur J Pediatr. 2019;178(10):1567-1576. doi:10.1007/s00431-019-03457-x

13. Danielle, W. et al. (2014). Elementary students' physical activity and enjoyment during active video gaming and a modified tennis activity. Journal of Physical Education and Sport, 14(3), 311.

14. De Lisi, R., \& Wolford, J. L. (2002). Improving children's mental rotation accuracy with computer game playing. The Journal of Genetic Psychology, 163, 272-282.

15. Di Palma, D., Rosa, R., \& Ascione, A. (2019). Experimental pedagogy: New technologies. Journal of Human Sport and Exercise, 14(2proc), S149-S158. doi:10.14198/jhse.2019.14.Proc2.01

16. Dyson, B. \& Grineski S. (2001) Using Cooperative Learning Structures in Physical Education, Journal of Physical Education, Recreation \& Dance, 72:2, 28-31, doi:10.1080/07303084.2001.10605831

17. Ennis, C. D. (2013). Implications of exergaming for the physical education curriculum in the $21 \mathrm{st}$ century. Journal of Sport and Health Science, 2(3), 152-157.

18. Epstein, L. H. et al. (2007). Choice of interactive dance and bicycle games in overweight and nonoverweight youth. Annals of Behavioral Medicine, 33(2), 124-131. 
19. Finco, M. D. et al. (2015). Exergaming as an alternative for students unmotivated to participate in regular physical education classes. International Journal of Game-Based Learning, 5(3), 1-10.

20. Finn, K. E., \& McInnis, K. J. (2014). Teachers' and students' perceptions of the active science curriculum: incorporating physical activity into middle school science classrooms. Physical Educator, 71(2), 234.

21. Hansen, L., \& Sanders, S. (2010). Fifth Grade Students' Experiences Participating in Active Gaming in Physical Education: The Persistence to Game. Journal of Research, 5(2), 33-40.

22. Hayes, E., \& Silberman, L. (2007). Incorporating video games into physical education. Journal of Physical Education, Recreation \& Dance 78 (3): 18-24.

23. Gao, Z. (2013). The Impact of an Exergaming Intervention on Urban School Children's Physical Activity Levels and Academic Outcomes. Asian Journal of Exercise \& Sports Science, 10(2).

24. Gao, Z., \& Chen, S. (2014). Are field-based exergames useful in preventing childhood obesity? A systematic review. Obesity Review, 15, 676e691.

25. Gao, Z. et al. (2015). A meta-analysis of active video games on health outcomes among children and adolescents. Obesity Reviews, 16, 783e794. http://dx.doi.org/10.1111/obr.12287.

26. Gao, Z. et al. (2013). Video game-based exercise, Latino Children's physical health, and academic achievement. American journal of preventive medicine, 44(3), S240-S246.

27. Gao Z., Lee J. E., Pope Z., \& Zhang D. (2016). Effect of Active Videogames on Underserved Children's Classroom Behaviors, Effort, and Fitness. Games for Health Journal 2016 5:5, 318-324. DOI: $10.1089 / \mathrm{g} 4 \mathrm{~h} .2016 .0049$

28. Gao, Z., Podlog, L., \& Huang, C. (2013). Associations among children's situational motivation, physical activity participation, and enjoyment in an active dance video game. Journal of Sport and Health Science, 2(2), 122-128.

29. Gao, Z., Pope, Z. C., Lee, J. E., \& Quan, M. (2019). Effects of Active Video Games on Children's Psychosocial Beliefs and School Day Energy Expenditure. Journal of clinical medicine, 8(9), 1268. DOI: $10.3390 / \mathrm{jcm} 8091268$

30. Gao, Z., Zhang, T., \& Stodden, D. (2013). Children's physical activity levels and psychological correlates in interactive dance versus aerobic dance. Journal of Sport and Health Science, 2(3), 146151.

31. George, A. M., Rohr, L. E., \& Byrne, J. (2016). Impact of Nintendo Wii games on physical literacy in children:Motor skills, physical fitness, activity behaviors, and knowledge. Sports, 4(1), 3.

32. Goran, M. I., \& Reynolds, K. (2005). Interactive multimedia for promoting physical activity (IMPACT) in children. Obesity Research, 13, 762-771.

33. Graves, L.E. et al. (2010). The physiological cost and enjoyment of Wii Fit in adolescents, young adults, and older adults. Journal of Physical Activity and Health, 7(3), 393-401.

34. Hammond, J. et al. (2014). An investigation of the impact of regular use of the Wii Fit to improve motor and psychosocial outcomes in children with movement difficulties: a pilot study. Child: care, health and development, 40(2), 165-175.

35. Hansen, L., \& Sanders, S. (2010). Fifth grade students' experiences participating in active gaming in physical education: The persistence to game. The ICHPER-SD Journal of Research in Health, Physical Education, Recreation, Sport \& Dance, 5(2), 33. 
36. Hoque, M. E. (2016). Three domains of learning: Cognitive, affective and psychomotor. The Journal of EFL Education and Research, 2(2), 45-52.

37. Höysniemi, J. (2006). Design and evaluation of physically interactive games. Tampere University Press.

38. Hwang, G. J., Yang, L. H., \& Wang, S. Y. (2013). A concept map-embedded educational computer game for improving students' learning performance in natural science courses. Computers \& Education, 69, 121-130.

39. Klein, M. J., \& Simmers, C. S. (2009). Exergaming: virtual inspiration, real perspi- ration. Young Consumers: Insight and Ideas for Responsible Marketers, 10, 35e45. doi:10.1108/17473610910940774.

40. Knowles A.M., Niven, A., \& Fawkner, S. (2011) A qualitative examination of factors related to the decrease in physical activity behavior in adolescent girls during the transition from primary to secondary school. J Phys Act Health 2011; 8: 1084-91.

41. Ko, S. (2002). An empirical analysis of children's thinking and learning using a computer game context. Educational Psychology, 22, 219-233.

42. Kooiman, B.J. \& Sheehan, D. P. (2014). The Efficacy of Exergames Played Proximally and Over the Internet on Cognitive Functioning for Online Physical Education, American Journal of Distance Education, 28:4, 280-291, DOI: 10.1080/08923647.2014.957946

43. Kooiman, B. J. \& Sheehan, D. P. (2015). The efficacy of exergames for social relatedness in online physical education. Cogent Education, 2(1), 1045808.

44. Lamboglia, C. M. et al. (2013). Exergaming as a strategic tool in the fight against childhood obesity: a systematic review. Journal of obesity, 2013, 438364. DOI: 10.1155/2013/438364

45. Lee, J. E., Xiang, P., \& Gao, Z. (2017). Acute effect of active video games on older children's mood change. Computers in Human Behavior, 70, 97-103.

46. Lieberman, D. A. (2006). What can we learn from playing interactive games? In P. Vorderer \& J. Bryant (Eds.), Playing video games: Motives, responses, and consequences (pp. 379-397). Mahwah, NJ:Erlbaum.

47. Lindberg R., Seo J., \& Laine, T. H. (2016). "Enhancing Physical Education with Exergames and Wearable Technology," in IEEE Transactions on Learning Technologies, vol. 9, no. 4, pp. 328-341, 1 Oct.-Dec. 2016

48. Limperos, A. M., \& Schmierbach, M. (2016). Understanding the relationship between exergame play experiences, enjoyment, and intentions for continued play. Games for health journal, 5(2), 100107.

49. Lu, C., \& Buchanan, A. (2014). Developing Students' Emotional Wellbeing in Physical Education, Journal of Physical Education, Recreation and Dance, 85:4, 28-33, DOI: 10.1080/07303084.2014.884433F

50. Lwin, M. O., \& Malik, S. (2012). The efficacy of exergames-incorporated physical education lessons in influencing drivers of physical activity: a comparison of children and preadolescents. Psychology of Sport and Exercise, 13(6), 756-760.

51. Marker, A. M., \& Staiano, A. E. (2015). Better together: outcomes of cooperation versus competition in social exergaming. Games for health journal, 4(1), 25-30. 
International Journal of Scientific and Technological Research

ISSN 2422-8702 (Online), DOI: 10.7176/JSTR/6-06-11

Special Issue of Educational Sciences, Vol.6, No.6, 2020

52. McKenzie, E. et al. (2017). Challenge activities for the physical education classroom: Affective learning outcomes. Strategies, 30(6), 39-44.

53. McNeillie G. (2019) Can dance exergaming impact adolescent girls' selfefficacy toward physical activity?, Journal of Physical Education, Recreation \& Dance, 90:2, 61-61, DOI: 10.1080/07303084.2019.1548186

54. Ministry of National Education, (2018a). İlköğretim Beden Eğitimi Ve Spor Dersi Öğretim Programı. Ankara

55. Ministry of National Education, (2018b). Ortaöğretim Beden Eğitimi Ve Spor Dersi Öğretim Programı. Ankara

56. Moher, D. et al. (2009) Preferred Reporting Items for Systematic Reviews and MetaAnalyses: The PRISMA Statement. Annals Int Med, 151:264-269.

57. Mueller, F., Agamanolis, S., \& Picard, R. (2003). Exertion interfaces: Sports over a distance for social bonding and fun. In Conference on human factors in computing systems, Proceedings of the SIGCHI conference on human factors in computing systems (pp. 561-568). Ft. Lauderdale, FL: Association of Computing Machinery, Conference on Human Factors in Computing Systems.

58. Nacakcı, Z., Dalkıran, E., \& Ece, A. S. (2017). Müzik Eğitimi Anabilim Dalı Özel Yetenek Sınavlarında Karşılaşılan Sorunlar Ve Çözüm Önerileri; Sistematik Derleme Çalışması. Abant İzzet Baysal Üniversitesi Ë̆itim Fakültesi Dergisi.

59. Norris, E., Hamer, M., \& Stamatakis, E. (2016). Active video games in schools and effects on physical activity and health: a systematic review. The Journal of pediatrics, 172, 40-46.

60. Nyberg G. \& Meckbach J. (2017) Exergames 'as a teacher' of movement education: exploring knowing in moving when playing dance games in physical education, Physical Education and Sport Pedagogy, 22:1, 1-14, DOI: 10.1080/17408989.2015.1112778

61. Oblinger, D. (2004). The next generation of educational engagement. Journal of Interactive Media in Education, 2004(1), 1-10.

62. O'Dea, J. (2003). Why do kids eat healthful food? Perceived benefits of and barriers to healthful eating and physical activity among children and adolescents. Journal of the American Dietetic Association, 103, 497-501.

63. O'Loughlin, E. K. et al. (2012). Prevalence and correlates of exergaming in youth. Pediatrics, $130(5), 806-814$.

64. Olson, C. K. (2010). Children's Motivations for Video Game Play in the Context of Normal Development. Review of General Psychology, 14(2), 180-187. DOI: 10.1037/a0018984

65. Papastergiou, M. (2009). Exploring the potential of computer and video games for health and physical education: A literature review. Computers \& Education, 53(3), 603-622.

66. Paw, M. J. C. A. et al. (2008). The motivation of children to play an active video game. Journal of Science and Medicine in Sport, 11(2), 163-166.

67. Perlman, D. J., Forrest, G. J., \& Pearson, P. J. (2012). Nintendo Wii: opportunities to put the education back into physical education. Australian Journal of Teacher Education, 37 (7), 1-10.

68. Pope, Z. C., Lewis, B. A., \& Gao, Z. (2015). Using the Transtheoretical Model to Examine the Effects of Exergaming on Physical Activity Among Children, Journal of Physical Activity and Health, 12(9), 1205-1212.

$\mathbf{1 6 4 | P}$ a g e

wWw.iiste.org 
69. Quennerstedt, M. (2015). Active video gaming in PE: a critical exploration. In: AERA - American Educational Research Association, Chicago, 2015

70. Quennerstedt, M. et al. (2016). Béatrice: Dance video games as a resource for teaching dance. Digital technologies and learning in physical education: Pedagogical cases, 69-85.

71. Reulbach, U. et al. (2013). Weight, body image and bullying in 9-year-old children. J Paediatr Child Health. 2013;49(4):E288-93.

72. Rhodes, R. et al. (2018). Predictors of stationary cycling exergame use among inactive children in the family home. Psychology of Sport and Exercise. 41. 10.1016/j.psychsport.2018.03.009.

73. Robertson, J. et al. (2016). Understanding the Importance of Context: A Qualitative Study of a Location-Based Exergame to Enhance School Childrens Physical Activity. PloS one, 11(8), e0160927.

74. Rosas, R. et al. (2003). Beyond Nintendo: design and assessment of educational video games for first and second grade students. Computers \& Education, 40(1), 71-94.

75. Rudella, J. L., \& Butz, J. V. (2015). Exergames: Increasing physical activity through effective instruction. Journal of Physical Education, Recreation \& Dance, 86(6), 8-15.

76. Sheehan, D., \& Katz, L. (2010). Using interactive fitness and exergames to develop physical literacy. Physical \& Health Education Journal, 76(1), 12-19.

77. Shewmake, C. J., Merrie, M. D., \& Calleja, P. (2015). Xbox Kinect Gaming Systems as a Supplemental Tool Within a Physical Education Setting: Third and Fourth Grade Students' Perspectives. Pedagogy-Elementary Physical Education, 72, 142-152.

78. Selewski, D.T. et al. (2013). Promising insights into the health related quality of life for children with severe obesity. Health Qual Life Outcomes. 2013;11:29. Published 2013 Mar 1. doi:10.1186/1477-7525-11-29

79. Slater, A., \& Tiggemann, M. (2010) Uncool to do sport: a focus group study of adolescent girls' reasons for withdrawing from physical activity. Psychol Sport Exerc 2010; 11: 619-26.

80. Staiano, A. E., \& Calvert, S. L. (2011). Exergames for physical education courses: Physical, social, and cognitive benefits. Child development perspectives, 5(2), 93-98.

81. Staiano, A. E., Abraham, A. A., \& Calvert, S. L. (2012). Motivating effects of cooperative exergame play for overweight and obese adolescents.

82. Staiano, A. E., Abraham, A. A., \& Calvert, S. L. (2013). Adolescent exergame play for weight loss and psychosocial improvement: a controlled physical activity intervention. Obesity, 21(3), 598-601.

83. Staiano, A. et al. (2011). Physical activity intervention for weight loss in overweight and obese adolescents. Poster presented at the biennial meeting of the Society for Research in Child Development, Montreal, Canada.

84. Staiano, A. E., Adams, M. A., \& Norman, G. J. (2019). Motivation for Exergame Play Inventory: Construct validity and relationship to game play. Cyberpsychology: Journal of Psychosocial Research on Cyberspace, 13(3).

85. Sun, H. (2012). Exergaming Impact on Physical Activity and Interest in Elementary School Children, Research Quarterly for Exercise and Sport, 83:2, 212-220 doi: 10.1080/02701367.2012.10599852 
86. Sun, H. (2013). Impact of exergames on physical activity and motivation in elementary school students: A follow-up study. Journal of Sport and Health Science, 2(3), 138-145.

87. Sun, H., \& Gao, Y. (2016). Impact of an active educational video game on children's motivation, science knowledge, and physical activity. Journal of Sport and Health Science, 5(2), 239-245.

88. Thembelihle, G. (2017). Explorıng Use Of Exergames In Physical Education Classes As A Way To Curb Obesity And Promote Health In Children And Adolescents In Zimbabwe. European Journal of Physical Education and Sport Science.

89. Tunçel Z. (2006). İşbirlikli Öğrenmenin Beden Eğitimi Başarısı, Bilişsel Süreçler Ve Sosyal Davranışlar Üzerindeki Etkileri. Doktora Tezi. Dokuz Eylül Üniversitesi Eğitim Bilimleri Enstitüsü, İzmir.

90. Tuğrul, B. et al. (2014). Oyunun Üç Kuşaktaki Değişimi. International Journal of Social Science, 27: $1-16$.

91. Vaghetti, C. A. et al. (2012). Using exergames as social networks: testing the flow theory in the teaching of physical education. Brazilian Symposium on Computers in Education (Vol. 23, No.1).

92. Vallabhajosula, S., Holder, J. B., \& Bailey, E. K. (2016). Effect of Exergaming on Physiological Response and Enjoyment During Recess in Elementary School-Aged Children: A Pilot Study. Games for health journal, 5(5), 325-332.

93. Vuuren, C. et al. (2019). Associations between overweight and mental health problems among adolescents, and the mediating role of victimization. BMC Public Health. 19. 10.1186/s12889-0196832-z.

94. Wagener, T. L. et al. (2012). Psychological effects of dance-based group exergaming in obese adolescents. Pediatric Obesity, 7(5), e68e74.

95. Watson, D., Mandryk, R. L., \& Stanley, K. G. (2013, October). The design and evaluation of a classroom exergame. In Proceedings of the First International Conference on Gameful Design, Research, and Applications (pp. 34-41). ACM.

96. Weir, L. (2008). Wii love learning: Using gaming technology to engage students. Edutopia. Retrieved September 25, 2008.

97. Whitehead, S., \& Biddle, S. (2008) Adolescent girls' perceptions of physical activity: a focus group study. Eur Phys Educ Rev 2008; 14: 243-62.

98. Winn, W. (2002). Current trends in educational technology research: The study of learning environments. Educational Psychology Review, 14(3), 331-351.

99. World Health Organization (WHO). (2020). Obesity and Overweight, [Online] Available: https://www.who.int/en/news-room/fact-sheets/detail/obesity-and-overweight (April 7, 2020). 